Available online at: www.cahiersagricultures.fr

\title{
Effect of supplementary irrigation on the transpiration and reproductive development of oil palm trees during the dry season in Tabasco, Mexico
}

\author{
José Hipólito Rodolfo Mendoza-Hernández ${ }^{1}$ (D), César J. Vázquez-Navarrete ${ }^{1}$ (D), \\ Luz del Carmen Lagunes-Espinoza ${ }^{1,{ }^{*}}$, Joaquín A. Rincón-Ramírez ${ }^{1,{ }^{*}}$, Nydia del Rivero-Bautista ${ }^{1}$ (D), \\ María del Carmen Pérez-Bonilla ${ }^{1}$ (D) José Gutiérrez-López ${ }^{2}$ (D) and Heidi Asbjornsen ${ }^{2}(\mathbb{D}$ \\ ${ }^{1}$ Colegio de Postgraduados, Campus Tabasco, Periférico Carlos A. Molina s/n, 86500 Heroica Cárdenas, Tabasco, Mexico \\ ${ }^{2}$ University of New Hampshire, Department of Natural Resources and the Environment, Durham, New Hampshire, USA
}

\begin{abstract}
Some oil palm production zones have periods of low rainfall, eliciting to water stress and impacting yields. The objective of this study was to evaluate the effect of the supplementary irrigation application during the dry season, on the water use and the transpiration of oil palm trees, and on morphological changes that occur during the different phenological stages. The monitored site was an oil palm plantation in Jalapa, Tabasco, Mexico $\left(17^{\circ} 38 \mathrm{~N} ; 92^{\circ} 56 \mathrm{~W}\right.$; altitude $\left.20 \mathrm{~m}\right)$. There, the plant density is $143 \mathrm{palms} \mathrm{ha}^{-1}$. Two areas of palm trees with ages of 6 and 11 years were located. The soil type was classified as Gleysol. A weather station was placed in a pasture adjacent $(1 \mathrm{~km})$ to the plantation. The variables, evaluated from April 1 to June 23, 2017, included the structural characteristics of the plantation, sap flow, transpiration, and the morphological changes at the different phenological stages, which were assessed based on the BBCH scale. The results showed that the water use per palm tree $\left(102-140 \mathrm{~kg} \mathrm{day}^{-1}\right)$ and the transpiration (1.59-2.11 mm day ${ }^{-1}$ ) were not significantly different among palm trees ages. The application of irrigation during the dry season maintained transpiration in palms of both ages and favoured inflorescence development and fruit formation by shortening the number of days it took the palm plants to reach fruit formation stage (stages 503-700), but increased the number of days required by the bunches to reach maturation (stages 709 to harvest). This study conducted during few months needs to be confirmed by longer term monitoring.
\end{abstract}

Keywords: transpiration / sap flow / supplementary irrigation / vapour pressure deficit / reproductive phenology

Résumé - Effet de l'irrigation complémentaire sur la transpiration et le développement reproductif du palmier à huile pendant la saison sèche à Tabasco, Mexique. Certaines zones de production du palmier à huile connaissent des périodes de faibles précipitations qui provoquent un stress hydrique et impactent les rendements. L'objectif de cette étude était d'évaluer l'effet de l'irrigation complémentaire pendant la saison sèche sur l'utilisation de l'eau et la transpiration des palmiers à huile, et sur les changements morphologiques qui se produisent au cours des différents stades phénologiques. Le site suivi était une plantation de palmiers à huile de Jalapa, Tabasco, Mexique $\left(17^{\circ} 38 \mathrm{~N} ; 92^{\circ} 56 \mathrm{O}\right.$, altitude $\left.20 \mathrm{~m}\right)$. La densité y est de 143 palmiers ha ${ }^{-1}$. Deux zones de palmiers âgés de 6 et 11 ans ont été localisées. Le sol est classé comme Gleysol. Une station météorologique a été installée dans un pâturage situé à $1 \mathrm{~km}$ de la plantation. Les variables évaluées incluaient les caractéristiques structurelles de la plantation, le flux de la sève et la transpiration, ainsi que les changements morphologiques aux différents stades phénologiques, qui ont été évalués sur la base de l'échelle $\mathrm{BBCH}$. Les résultats ont montré que l'utilisation de l'eau par chaque palmier $\left(102-140 \mathrm{~kg} \mathrm{jour}^{-1}\right)$ et la transpiration $\left(1,59-2,11 \mathrm{~mm}\right.$ jour $\left.^{-1}\right)$ n'étaient pas significativement différentes selon l'âge des palmiers. L'application de l'irrigation pendant la saison sèche a maintenu la transpiration dans les palmiers des deux âges et a favorisé le développement de

\footnotetext{
*Corresponding authors: lagunesc@colpos.mx; jrincon@colpos.mx
} 
l'inflorescence et la formation des fruits en raccourcissant le nombre de jours nécessaires aux palmiers pour atteindre le stade de formation des fruits (stades 503-700), mais a augmenté le nombre de jours nécessaires aux régimes pour atteindre la maturation (stades 709 à la récolte). Cette première étude de quelques mois nécessitera d'être confirmée par un suivi sur plusieurs années.

Mots clés : transpiration / flux de sève / irrigation complémentaire / déficit de pression de vapeur / phénologie reproductive

\section{Introduction}

Oil palm trees (Elaeis guineensis Jacq.) are extensively cultivated in Asia, where $87.2 \%$ of palm oil is produced. Only $5.9 \%$ of palm oil is produced in America (FAOSTAT, 2020). In Mexico, $95 \%$ of the oil palm plantations are established in the areas of Veracruz, Tabasco, Campeche and Chiapas. These locations previously hosted staple food crops and cattle grazing areas (Hernández-Rojas et al., 2018). In these regions, the cultivated area of oil palm trees (OP) is 90118 ha; only $6.7 \%$ of this area is irrigated. In Tabasco, there are 16195 ha of OP, and none of this area is irrigated; the OP in Tabasco produce $163000 \mathrm{t}$ of fresh fruit bunches (FFB), with an average yield of $14.8 \mathrm{tha}^{-1}$ (SIAP, 2017). In Tabasco, the annual average precipitation varies between $2214-3862 \mathrm{~mm}$ and temperature ranges between 22 $26.8^{\circ} \mathrm{C}$, presenting suitable conditions for OP production. For OP growth, the precipitation must be distributed throughout the year, and the minimum monthly precipitation required to cover the water needs of OP is $150 \mathrm{~mm}$ (Carr, 2011; Ochs and Daniel, 1976). Otherwise rainfall $<100 \mathrm{~mm}$, the OP production shrinks by approximately $10 \%$ as key physiological, reproductive and yield processes are affected (Cornaire et al., 1994; Rivera et al., 2012; Corley and Tinker, 2015).

The effect of water deficit on fruit yields and the use of irrigation to improve the productivity of OP plantations are well known in Asia, where irrigation is a key practice, especially during the dry season, allowing OP to reach optimal yields (Carr, 2011). In Tabasco, the precipitation distribution is not uniform throughout the year, showing months with low or null precipitation. Although the dry season can affect OP production, the producers in Tabasco do not apply management practices to alleviate the drought. The availability of water is not limiting since there are sufficient sources of both surface and underground water. So, a wise use of supplementary irrigation as a tool to reduce water stress and increase productivity of OP, would not compromise water resource use by other activities in the region, while allowing the palm trees to perform better during the drought period. However, there are no studies relating the benefits of irrigation during dry months to the productivity of OP in the region. In Mexico, agronomic studies of OP cultivation have focused mainly on soil fertility (Salgado-García et al., 2017), soil suitability (Palma-López and Triano, 2002), and the quality of water used for irrigation (Palma-López et al., 2017).

Sap flow is among the physiological traits allowing the OP responses to water status changes to be measured in situ (Henson et al., 2005; Kallarackal et al., 2004). Sap flow in OP can be evaluated using the thermal dissipation probe (TDP) method (Röll et al., 2015). OP transpiration depends on the vapour pressure deficit (VPD), so that at higher VPD values $(>1.8 \mathrm{kPa})$ around $\mathrm{OP}$ crown, up to a certain level, transpiration rates and sap flow decrease, as well as stomatal conductance (Dufrene and Saugier 1993; Röll et al., 2015).
The hypothesis raised is that the use of the TDP method to evaluate the water status of palm trees in irrigation experiments can facilitate the measurement of OP water demand, if this is accompanied by monitoring the development of inflorescence until fruit ripening. According to Forero et al. (2012), this monitoring can be carried out using the $\mathrm{BBCH}$ scale (Biologische Bundesantalt, Bundessortenamt und Chemische Industrie; Bleiholder et al., 1991; Meier, 1997), since the changes in the development of the inflorescences are morphologically visible. Information could be used by producers to develop an irrigation programme during the dry season and mitigate stress occurring due to water deficits in plantations in Mexico.

The objective of this study was to determine transpiration by the sap flow measurement and to monitor changes during development of female inflorescences and fruits ripening in OP of 6 and 11 years old in the dry season in response to supplementary irrigation in Tabasco, Mexico.

\section{Materials and methods}

\subsection{Research area}

This study was carried out in a commercial OP plantation of Deli $\times$ Ghana variety located in Tacotalpa, Tabasco, Mexico at 17.647 North latitude and 92.826 West longitude and at 20 m.a.s.l (Fig. 1). The weather is humid and warm with abundant rainfalls throughout the year, but a dry season occurs during April and May ( $<150 \mathrm{~mm}$ monthly precipitation). Two OP sites were chosen in the plantation, one with 6-year-old OP (6yOP) and the other with 11-year-old OP (11yOP). The soil type was classified as Gleysol. It exhibits water saturation during the rainiest month of the year (October), and seasonal fluctuations in the groundwater table ( 3 and $5 \mathrm{~m}$ deep, in rainy and dry season, respectively). The spatial topology was a triangular configuration of $9.0 \mathrm{~m}$ by $9.0 \mathrm{~m}$ with a density of $143 \mathrm{palms} \mathrm{ha}^{-1}$. Agricultural labour activities including pruning of lower leaves, fertilizer and pesticide application, and regular fruit harvesting, were performed based on the OP Technological Guide (INIFAP, 2011). The experimental design established in the existing plantation was a random block with a $2 \times 2$ factorial. The factors studied were the OP age (6 and 11 years old plantations) and irrigation (with and without). Palms without irrigation were the control treatment. In the irrigation treatment, 16 palms of each age were selected, to avoid edge effect. In the plots with palms of the same age, the distance between the control and irrigated treatment was $24 \mathrm{~m}$. The distance between the plots with palms of 6 and 11 years was $100 \mathrm{~m}$. The experiment consisted of $2 \times 2$ treatments. Five repetitions per treatment were used for measurement (one palm tree being one repetition).

To determine the evapotranspiration needs of OP for crop irrigation, Cropwat 8.0-FAO (http://www.fao.org/land-water/ 

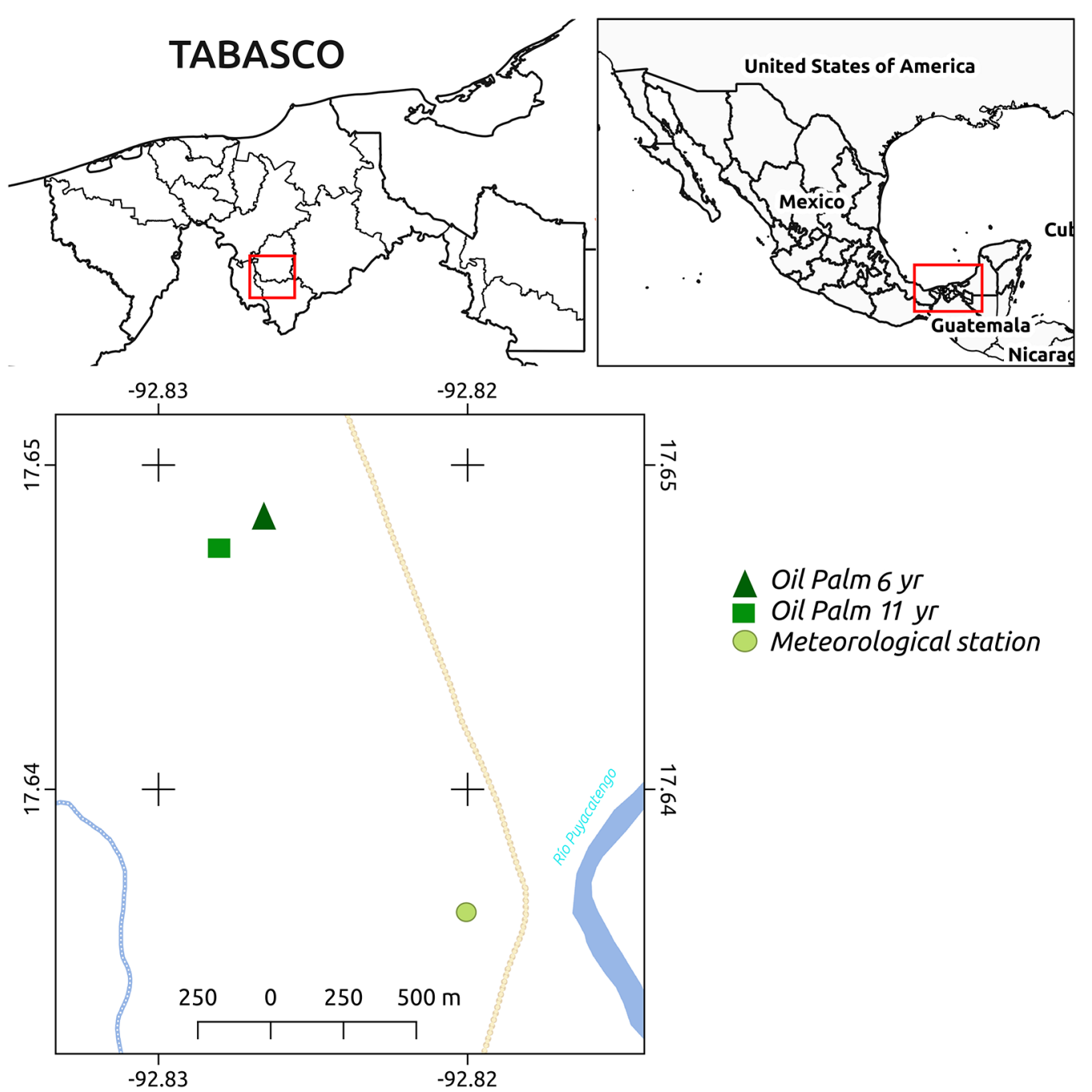

Fig. 1. Research sites in the oil palm plantation in Tacotalpa, Tabasco, Mexico.

Fig. 1. Sites de recherche dans la plantation de palmiers à huile à Tacotalpa, Tabasco, Mexique.

databases-and-software/cropwat/es/) was used. The irrigation system consisted of micro-sprinklers each with a wetting diameter of $1.15 \mathrm{~m}$. Two micro-sprinkler emitters were installed per palm, and the following irrigation parameters were established: operating pressure of 15-20 psi, flow rate discharged of $48 \mathrm{lh}^{-1}$, and a weekly scheduling program with $2 \mathrm{~h}$ of irrigation (i.e., $192 \mathrm{~L}$ of water was emitted weekly to each palm during the study).

After the installation of the irrigation system, a total of 4 automatic sap flow monitoring stations were set, with one station for each site. Each station consisted of a multiplexor AM16/32 model and datalogger CR1000 (Campbell Scientific Inc., Logan, Utah, USA), to register sap flow (Granier, 1985). Five palm trees were selected per site, and in each tree, three leaf petioles were chosen near the base of the crown, oriented to the North, West and South. In each leaf petiole, a $20 \mathrm{~mm}$ long TDP was installed. In total, 15 TDP sensors were installed in the base of the leaf petioles (Niu et al., 2015). Each TDP sensor was protected by an insulating aluminium foil, in order to reduce temperature gradients, rain and solar radiation.

\subsection{Micro-meteorological variables}

One meteorological station was placed in a pasture plot located one kilometer from the study sites, with sensors to register the air temperature $\left({ }^{\circ} \mathrm{C}\right)$, relative humidity, PPFD (Photosynthetic photon flux density), solar radiation $\left(\mathrm{MJ} \mathrm{m}^{-2}\right)$, wind speed $\left(\mathrm{m} \mathrm{s}^{-1}\right)$ and rainfall $(\mathrm{mm})$ every $15 \mathrm{~min}$. Data were registered with a data logger (CR1000, Campbell Scientific, Inc. Salt Lake City, Utah. USA). The VPD (kPa) was calculated by using the relative humidity and air temperature (Allen et al., 1994).

\subsection{Structural characteristics of oil palm and phenology bunch stages}

The number of leaves on each OP was counted based on the phyllotaxis (the spear leaf was tagged) of each palm per treatment and age. The leaf area index (LAI) was determined at the canopy level of palms, with a Plant Canopy Analyser, model LAI-2000, LI-COR. The sequence of measurements by 
treatment and age of palms was a reading taken outside the plantation in an open area (above canopy), followed by four readings taken inside the plantation under the canopy of palms by treatment (below canopy). This sequence was repeated three times. The phenological growth stages of fruit development were recorded weekly in each phytomer, a large leaf axillating a fruit bunch (Fan et al., 2015) during the research period by using the $\mathrm{BBCH}$ scale (Forero et al., 2012).

\subsection{Sap flow density, palm water use and transpiration}

The sensor signals were recorded every $1 \mathrm{~min}$, averaged and stored every $15 \mathrm{~min}$. The $\mathrm{mV}$-data from the datalogger were transformed to sap flow density (Js, $\mathrm{g} \mathrm{cm}^{-2} \mathrm{~h}^{-1}$ ) measurements using the calibration equation of Granier (1985): JS $=\mathrm{aK}^{\mathrm{b}}$. The parameter values of the calibration equation developed by Niu et al. (2015) were used: $\mathrm{a}=48.24$ and $\mathrm{b}=1.61 . \mathrm{K}$ is defined as:

$$
K=\frac{\Delta T \max -\Delta T}{\Delta T}
$$

where $\Delta \operatorname{Tmax}\left({ }^{\circ} \mathrm{C}\right)$ is the temperature difference between the heated and reference probes under zero-flow conditions, and $\Delta \mathrm{T}\left({ }^{\circ} \mathrm{C}\right)$ is the temperature difference at a given time-step.

The water use rates of individual leaves were calculated by multiplying the respective sap flow densities (Js) by the conductive area (Ac) of the leaf petioles (the Ac was calculated from the leaf petiole segments located between both TDP sensors). Ten leaf segments, in the same position, from other nearby palms were used; the basal segment area was traced on paper, the baseline length $(\mathrm{cm})$ was measured. The water use rates of all individual leaves per palm measured with TDP simultaneously were averaged $(\mathrm{kg}$ $\left(\mathrm{day}^{-1}\right)$. To scale up to the average palm water use, the average leaf water use rates were multiplied by the average total number of leaves per palm age $\left(\mathrm{kg} \mathrm{day}^{-1}\right)$. Finally, multiplying the average palm water use by the number of palm trees per hectare resulted in transpiration rates $\left(\mathrm{T}, \mathrm{mm}^{\mathrm{day}}{ }^{-1}\right)$.

\subsection{Statistics analysis}

The data were analysed under a totally random experimental design with factorial $2 \times 2$, and 5 repetitions per factor. The factors were the OP age (6 and 11 years old) and irrigation (with and without). All data were subjected to variance analysis using the statistics program SAS (2018) version 9.04. Mean Tukey tests were carried out $(\alpha=0.05)$ to identify treatment differences.

\section{Results}

\subsection{Weather conditions}

Weather conditions, during research period from April 20 to June 23, 2017, are shown in Figure 2.
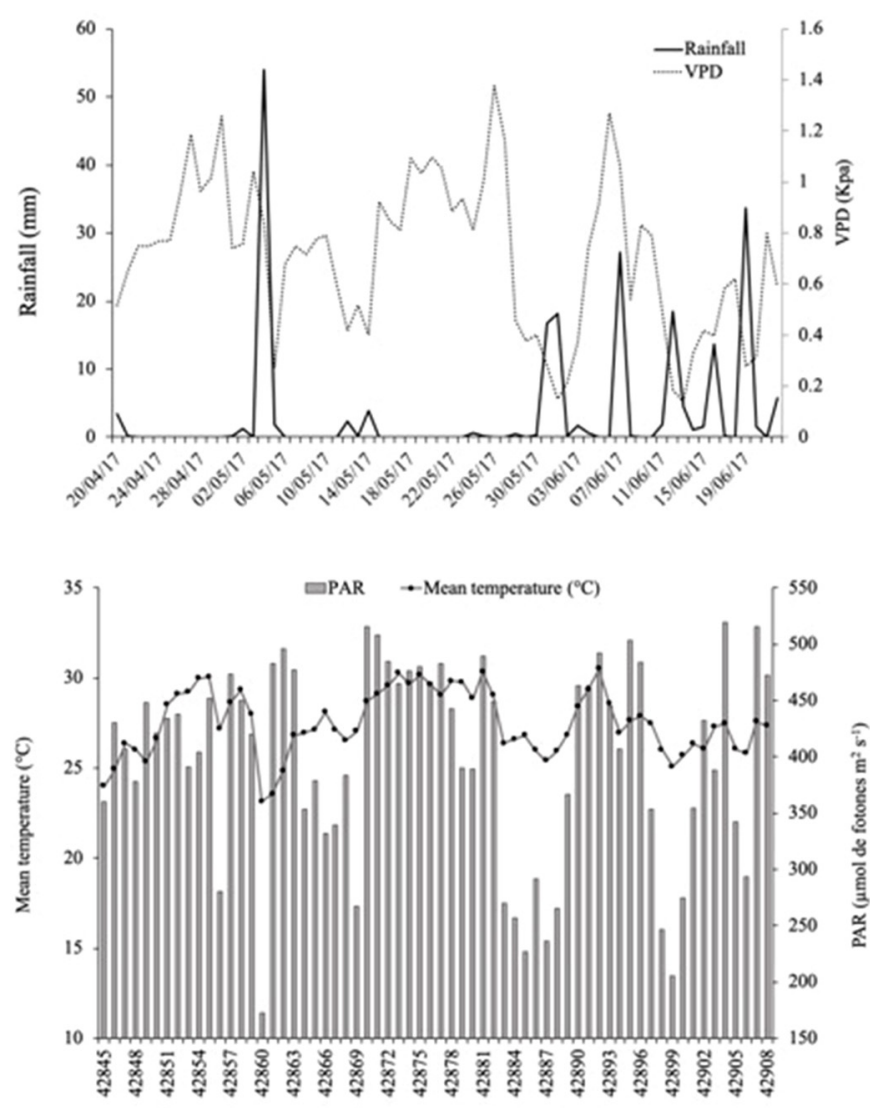

Fig. 2. Rainfall (mm), VPD $(\mathrm{kPa})$, average temperature $\left({ }^{\circ} \mathrm{C}\right)$ and photosynthetically active radiation (PAR, $\mu \mathrm{mol} \mathrm{m}^{-2} \mathrm{~s}^{-1}$ ) in oil palm plantations in Tacotalpa, Tabasco, during the research period.

Fig. 2. Précipitations ( $\mathrm{mm}), \mathrm{DPV}(\mathrm{kPa})$, température moyenne $\left({ }^{\circ} \mathrm{C}\right)$ et rayonnement photosynthétiquement actif (RPA, $\mu \mathrm{molm} \mathrm{m}^{-2} \mathrm{~s}^{-1}$ ) dans la plantation de palmiers à huile à Tacotalpa, Tabasco, pendant la période de recherche.

\subsection{Structural characteristics of oil palms}

Regarding the structural characteristics of the studied OP, differences were observed only in the LAI. The water conductive areas ranged from $25.2 \pm 4.7$ to $33.9 \pm 3.0 \mathrm{~cm}^{2}$; the $11 \mathrm{yOP}$ plot showed the highest value and the 6yOP plot showed the lowest value. The number of new leaves that emerged during the period was 6 per palm in each treatment, and the total numbers of leaves per palm were $40.0 \pm 2.0$ and $38.6 \pm 1.15$ in the irrigated and control 6yOP plots, respectively, and $36.3 \pm 1.52$ and $37.6 \pm 1.52$ in the irrigated and control 11yOP plots, respectively. The LAI values varied from $2.9 \pm 0.10$ to $4.0 \pm 0.07$; the $11 \mathrm{yOP}$ showed the highest value. The 6yOP did not show significant differences in their average LAI values $(3.0 \pm 0.02$ in control palms; $3.2 \pm 0.08$ in irrigated palms).

\subsection{Sap flow density}

The average sap flow density $\left(\mathrm{Js}, \mathrm{g} \mathrm{cm}^{-2} \mathrm{day}^{-1}\right)$ did not show differences due to age or irrigation effect. The range of 
Table 1. Density of maximum sap flow in petioles $\left(\mathrm{g} \mathrm{cm}^{-2} \mathrm{day}^{-1}\right)$, water use per palm $\left(\mathrm{kg} \mathrm{day}^{-1}\right)$ and estimated transpiration of the plantation $\left(\mathrm{mm} \mathrm{day}^{-1}\right)$ of oil palm at two ages. Means and standard deviation.

Tableau 1. Densité du flux de sève maximal dans les pétioles $\left(\mathrm{g} \mathrm{cm}^{-2} \mathrm{jour}^{-1}\right)$, utilisation d'eau par palmier $\left(\mathrm{kg}_{\text {jour }}{ }^{-1}\right)$ et transpiration estimée de la plantation $\left(\right.$ mm jour $^{-1}$ ) de palmier à huile à deux âges. Moyennes et écart type.

\begin{tabular}{llrr}
\hline Treatment & $\begin{array}{l}\text { Js maximum } \\
\left(\mathrm{g} \mathrm{cm}^{-2} \mathrm{day}^{-1}\right)\end{array}$ & $\begin{array}{l}\text { Water use } \\
\left(\mathrm{kg} \mathrm{day}^{-1}\right)\end{array}$ & $\begin{array}{l}\text { Transpiration rate } \\
\left(\mathrm{mm} \mathrm{day}^{-1}\right)\end{array}$ \\
\hline 6 year old irrigated & $16.51 \pm 4.0$ & $117.89 \pm 27.6$ & $1.69 \pm 0.38$ \\
6 year old control & $17.16 \pm 4.6$ & $140.3 \pm 47.4$ & $2.11 \pm 0.58$ \\
11 year old irrigated & $15.55 \pm 8.5$ & $114.17 \pm 32.0$ & $1.70 \pm 0.34$ \\
11 year old control & $14.91 \pm 2.8$ & $102.75 \pm 82.1$ & $1.59 \pm 0.47$ \\
\hline
\end{tabular}

variation in Js was from $15.55 \pm 8.5$ to $17.16 \pm 4.6 \mathrm{~g} \mathrm{~cm}^{-2}$ day $^{-1}$ (Tab. 1). At the diurnal level, no significant variations were observed between treatments, or between palm ages during the hours of maximum Js. Js increased between 10 and $12 \mathrm{~h}$ in the control 6yOP, with a maximum value recorded approximately at $11 \mathrm{~h}\left(17.1 \mathrm{~g} \mathrm{~cm}^{-2}\right.$ day $\left.^{-1}\right)$, in comparison with the irrigation treatment, where the maximum increase was observed between 8 and $10 \mathrm{~h}$ (Fig. 3 ). In the control 11yOP, the maximal Js values were observed at $9 \mathrm{~h}\left(15.5 \mathrm{~g} \mathrm{~cm}^{-2}\right.$ day $\left.^{-1}\right)$. The Js values also increased as the VPD rose. The maximum value of Js recorded for the control 6yOP was observed with a VPD of $1.49 \mathrm{kPa}$, and for irrigated palms, this value was $1.23 \mathrm{kPa}$. In the $11 \mathrm{yOP}$, irrigated palms, the maximum Js was recorded at a VPD of $1.49 \mathrm{kPa}$, and in control palms, it was at $1.2 \mathrm{kPa}$ (average from 9 to $12 \mathrm{~h}$ ). The water use per palm $\left(\mathrm{kg} \mathrm{day}^{-1}\right)$ in the control palms ranged between 131 and $152 \mathrm{~kg} \mathrm{day}^{-1}$. Although there was no significant difference between palm trees of different ages (Tab. 1), the 11yOP showed more variation during this period (Fig. 3). The transpiration rate also showed an increase in the 6yOP with no irrigation, reaching $2 \mathrm{~mm}$ day $^{-1}$ (Tab. 1).

\subsection{Irrigation effect on phenological growth stages of fresh fruit bunches (FFB)}

Table 2 shows the significant effect of the palm age on the stages of emergence of male and female inflorescences BBCH codes 501, 505, 509; male and female inflorescence flowering codes of 601 and 609M; fruit development codes of 700 and 708 ; and ripening of the fruits and the bunches codes of 800 to 807 . The effects of the irrigation treatments were significant for development stages with codes 501, 602M and for those from 703 to 805 . The interaction between palm age and irrigation was significant for the development stages with codes 501, $602 \mathrm{M}, 607 \mathrm{M}, 609 \mathrm{M}$ and from 700 to 709 .

\subsection{Dynamics of changes in the phenological stages of phytomers}

In the Figure 4, the development of the phenological stages of OP bunches is shown. In the irrigated-6yOP, phytomers in the stages of the emergence of female inflorescences (codes 503 and 509), required approximately 80 days to reach the stage of fruit development (code 700). In contrast, in the control palms, phytomers of code 503, reached only the end of flowering stage (code 609) in the same number of days. The phytomers of codes 609 and 700 did not show differences in the number of days required to pass to $80 \%$ of the fruit size (code 708) between the irrigated and control palms. Phytomers of code 708 were harvested in 72 days in irrigated OPs and in 79 days in the control OPs. Finally, the phytomers of code 709 (full fruit size stage) took 79 days to be harvested in the irrigated OPs and 63 days in the control palms.

The analysis of the 11yOP (Tab. 2, Fig. 4) showed significant differences in the development of female inflorescences and fruit maturation between the irrigated and control palms. These differences manifested in the number of days required to pass from code 503 to 609 . While the control OPs required approximately 79 days to reach the end of flowering (code 609), in the same number of days, the irrigated palms reached fruit development (code 700). Finally, in the irrigated palms, the phytomers of code 708, passed to the code 805 (fruit almost ripe) in 79 days, while the control palms reached code 807 (fruit with ripe colour in all surfaces) in the same number of days.

\section{Discussion}

OP can suffer from water deficits when the dry season is marked by 3 to 4 months even for precipitation totals of 1000 $1500 \mathrm{~mm}$ year $^{-1}$ or for minimum optimal monthly rainfall levels of $150 \mathrm{~mm}$ (Ochs and Daniel, 1976), as these conditions affects the opening of stomata for transpiration as well as the photosynthetic rate (Ochs and Daniel, 1976), and the yield (Carr, 2011). Water deficits were observed during three months in this study, in April (146.6 mm), May $(68.2 \mathrm{~mm})$ and June $(20.2 \mathrm{~mm})$. These values were similar to those observed in OP plantations in Malaysia during the dry season (Corley and Tinker 2015).

The number of leaves per palm has a direct relationship with the LAI and the optimal LAI value for a mature OP is 5-7 (Breure, 2010). Due to the lower number of leaves observed in the studied OP, the LAI values were also low. Low LAI values represent less light interception, which can relent the development of leaves, and indirectly foster the process of fruit formation (Legros et al., 2009; Hoffman et al., 2014). Water stress during the dry season in the studied OP plots did not affect the production of new leaves (6) or the number of leaves per palm (35 to 41). Nevertheless, the number of leaves was inferior to what Carr (2011) observed for grown palm trees ( $>8$-years-old) under normal rainfall (40 to 50 leaves). As there is no information about the temporal dynamics of leaf 

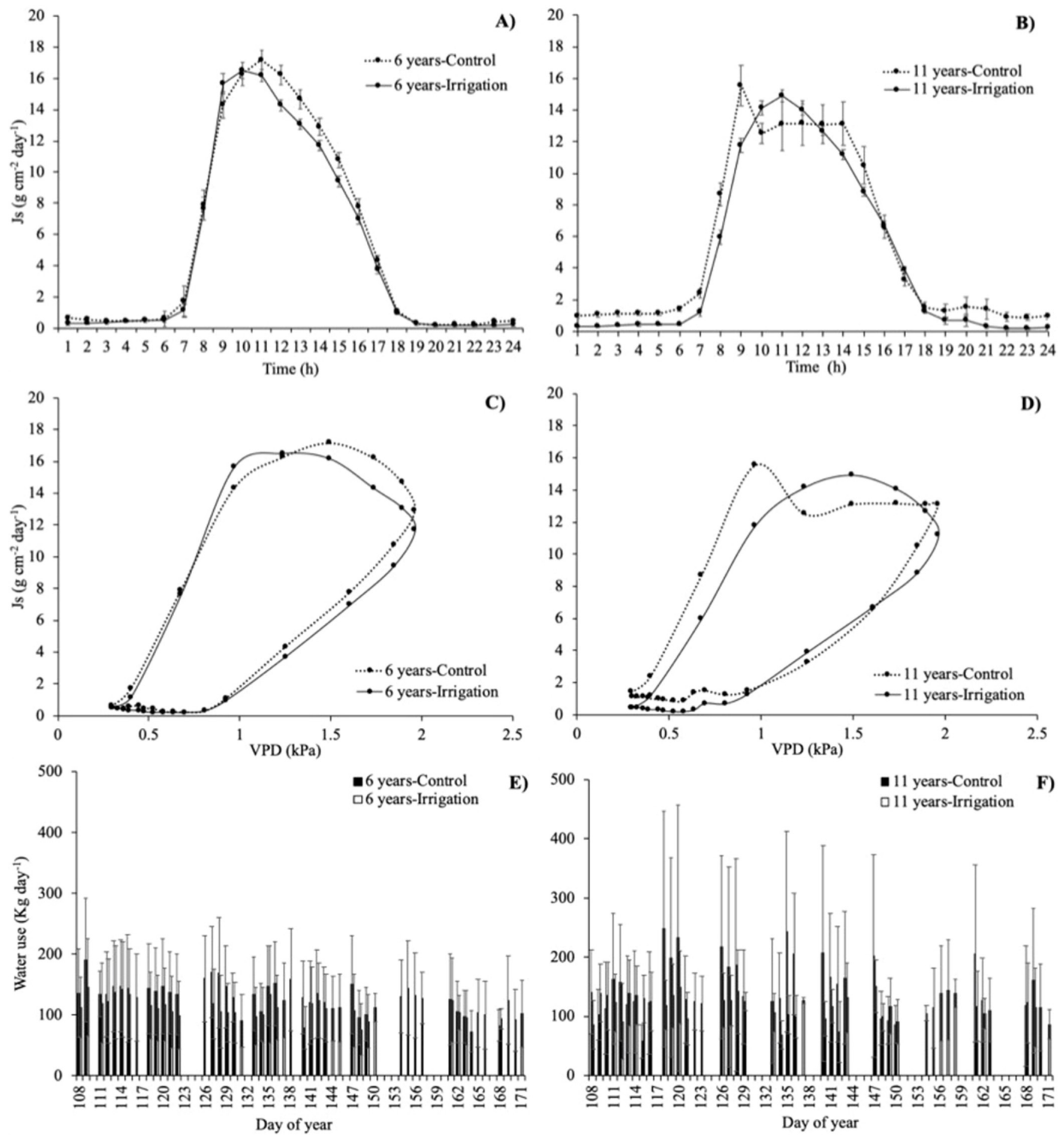

Fig. 3. Diurnal variations in sap flow density $\left(\mathrm{g} \mathrm{cm}^{-2} \mathrm{day}^{-1}\right)$ in 6-year-old palms (A) and 11-year-old palms (B); the relationship between sap flow and VPD (C, D); and water used per palm $\left(\mathrm{kg}\right.$ day $\left.^{-1}\right)$ of 6-year-old (E) and 11-year-old (F) palms in control and irrigated treatments during the dry season in Tacotalpa, Tabasco, Mexico.

Fig. 3. Variation diurne de la densité de flux de sève $\left(\mathrm{g} \mathrm{cm}^{-2}\right.$ day $\left.{ }^{-1}\right)$ chez les palmiers de 6 ans $(A)$ et 11 ans $(B)$; et sa relation avec DPV $(C$, D),

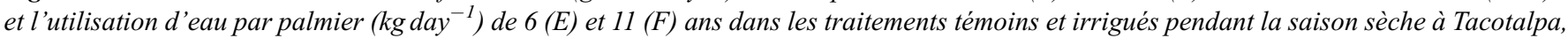
Tabasco, Mexique. 
Table 2. Probability values of the analysis of variance for the presence of reproductive stages, in response to palm age, irrigation, and their interaction, in the oil palm plantation under study.

Tableau 2. Valeurs de probabilité de l'analyse de variance pour la présence de stades de reproduction, en réponse à l'âge du palmier, l'irrigation et leur interaction, dans la plantation de palmiers à huile étudiée.

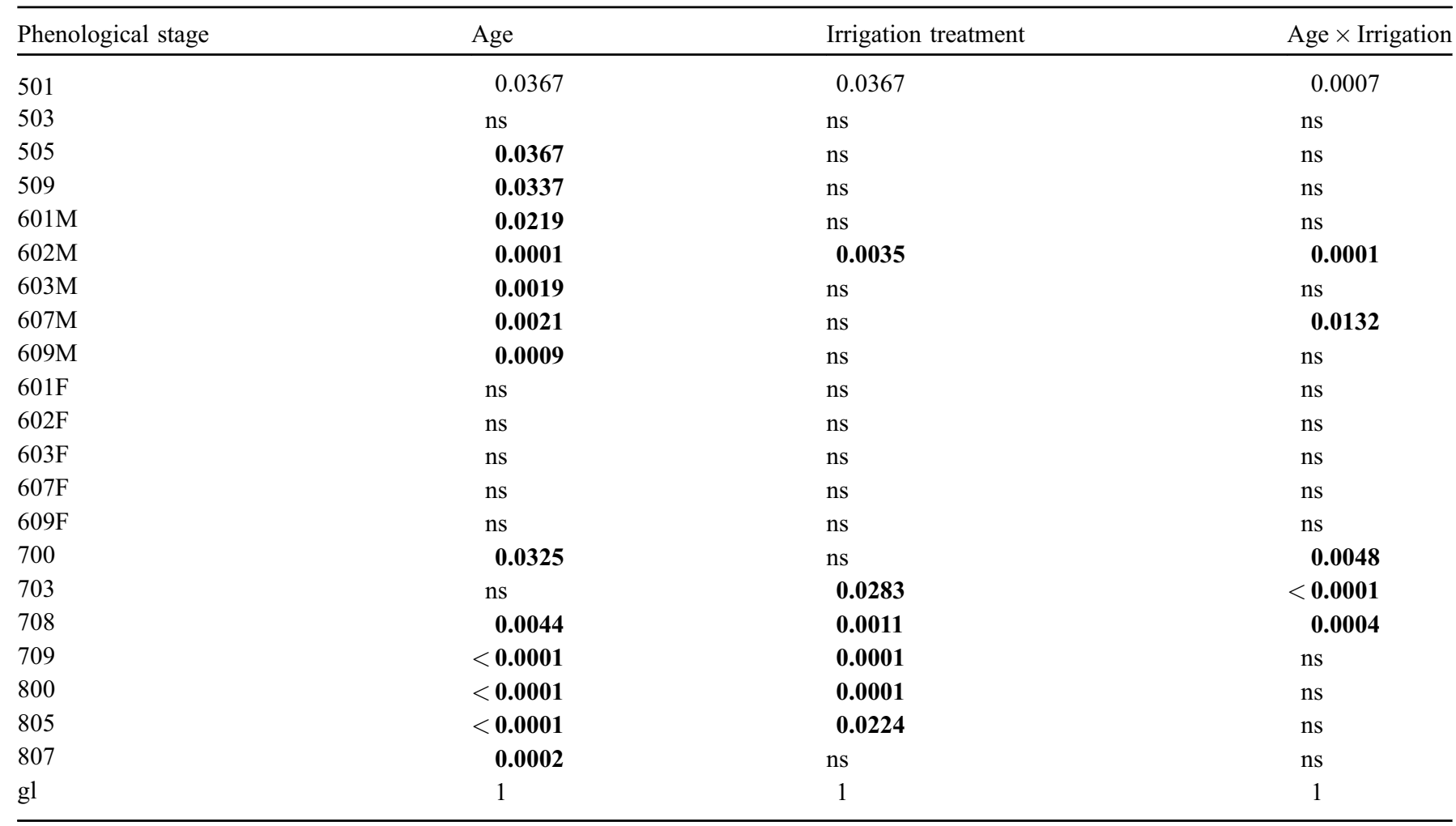

ns: non significant at $p \leq 0.05 ; \mathrm{M}$ : masculine; $\mathrm{F}$ : feminine.

production at different OP ages with different agronomic practices (e.g., irrigation), or their relation to yield, more longterm studies are necessary.

OP trees require a vast amount of water to reach their production potential since they have an average evapotranspiration potential rate ranging from 4 to $5.5 \mathrm{~mm}^{-1 a y}{ }^{-1}$ (Corley and Tinker, 2015); a palm tree can use 140 to $384 \mathrm{~L}$ of water daily (Kallarackal et al., 2004). Water use varies between regions of OP production; in our study, with a density of $143 \mathrm{palms} \mathrm{ha}^{-1}$, the use of water ranged from 102 to $140 \mathrm{~kg} \mathrm{day}^{-1}$, although no significant differences were observed between treatments. Similarly, the transpiration rates can vary among OP trees and plantation density in different regions. Recently, Niu et al. (2015) observed transpiration rates of $1.1 \mathrm{~mm} \mathrm{day}^{-1}$. Kallarackal et al. (2004) estimated transpiration rates of 2.0 to $5.5 \mathrm{~mm} \mathrm{day}^{-1}$ in palms under irrigation in India, and Dufrene et al. (1992) obtained measures of 1.2 to $2.5 \mathrm{~mm} \mathrm{day}^{-1}$ in 12 -m-high palms without irrigation in Ivory Coast. Röll et al. (2015) observed transpiration rates ranging from 1.0 to $2.5 \mathrm{~mm} \mathrm{day}^{-1}$ in Indonesian palms between 9 and 12 years old; these values later stabilized at approximately $1.3 \mathrm{~mm} \mathrm{day}^{-1}$ in older palms. In our study, the obtained transpiration rates varied from $1.59 \mathrm{~mm} \mathrm{day}^{-1}$ (control-11yOP) to $2.11 \mathrm{~mm} \mathrm{day}^{-1}$ (control-6yOP) (Tab. 1). No significant differences were observed between 11yOP with and without irrigation and irrigated-6yOP (Tab. 1). The higher transpiration rate in 6yOP could be attributed to higher productivity at the palm level, although we did not count the number of bunches produced per palm tree during the study period. Röll et al. (2015) pointed out that the management of plantations and productivity at the palm level could contribute to a greater use of water and therefore to increased transpiration rate.

The sap flow density did not vary between the control and irrigated palms, but diurnal variations were observed, with maximum values between 9 and $11 \mathrm{~h}$. The sap flow density increased when the VPD increased. Hardanto et al. (2017) observed similar results in 16 year-old palm trees planted at densities of 132 to 144 palms ha $^{-1}$, subjected to different soil humidity levels, the cumulative daily sap flow density increased with VPD and radiation.

The supplementary water applied by irrigation over short periods (dry season) did not modify the water flux in the OP in this study. The OP trees seemed to buffer changes in water availability, which may be associated with low dynamic in leaf growth with implications for the leaf area, and production of bunches. The presence of epiphytes attached to palm trunks could also contribute to water storage. The climatic conditions present during the experimental period, such as the intermittent rains that decreased the temperature and the photosynthetically active radiation, could have contributed to reducing the differences in soil moisture, and the response of OP trees to VPDs. Long terms studies are necessary to observe the dynamics of palm growth. In dry periods without rainfall and 

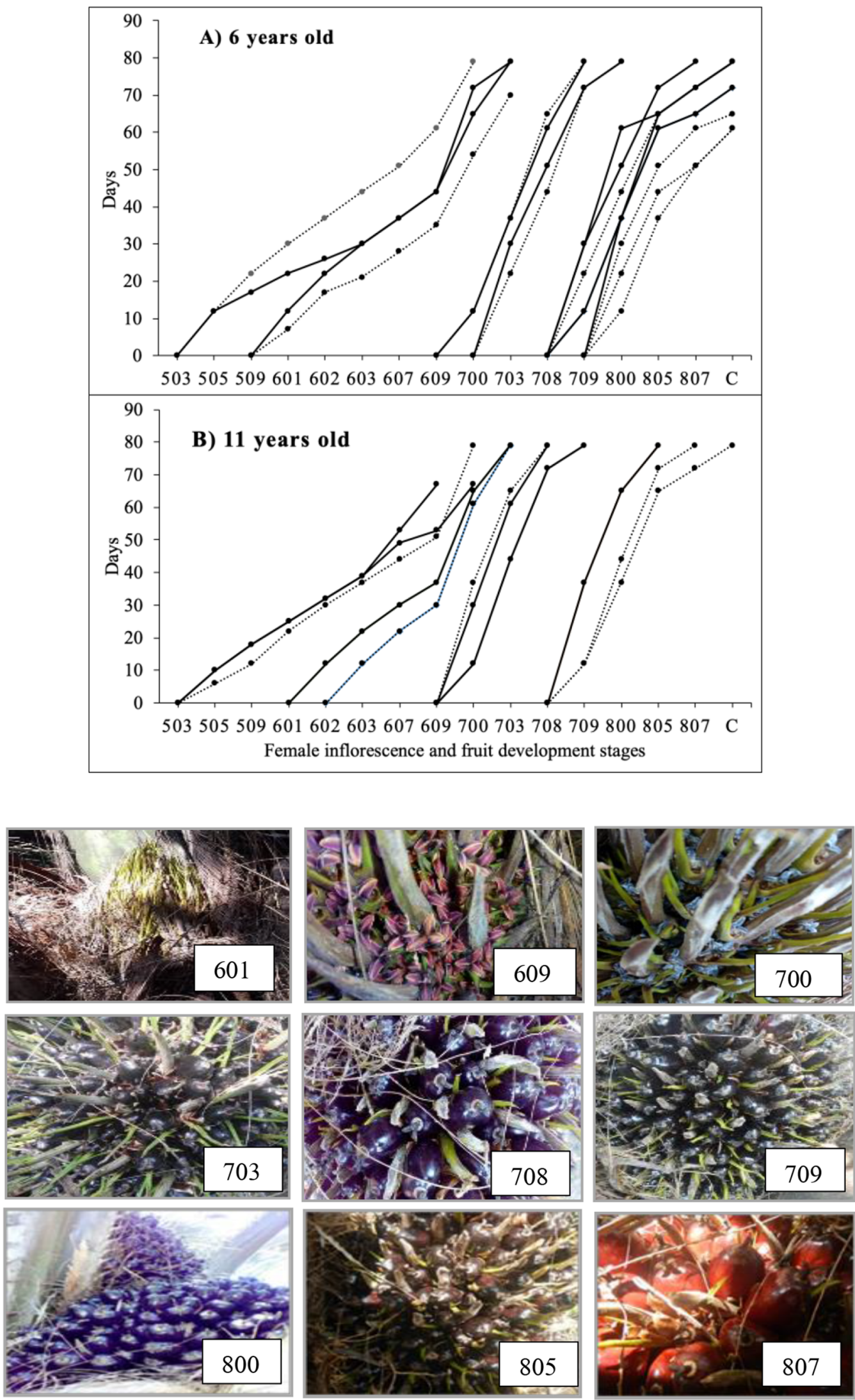
Fig. 4. Dynamics of phenological stage changes in female inflorescences and fruit development in 6-year-old (A) and 11-year-old (B) palms with and without irrigation.

Solid lines indicate control oil palms and dotted lines indicate oil palms with irrigation. The photos show the evolution of the female inflorescence from pre-anthesis stage until fruiting. The BBCH code were as follows (Forero et al., 2012): 601 represents the pre-anthesis stage of the female inflorescence. 607 represents anthesis of female inflorescence. 609 represents the end of flowering. 700 represents the fertilized female flower stage. 703 represents the stage at which $30 \%$ of the final fruit size has been reached. 708 represents $80 \%$ of the final fruit size. 709 represents full-sized fruits according to the variety. 800 indicates the stage at which the fruit reaches its final size and changes colour from the bottom to the tip to its characteristic ripe color. 805 represents almost-ripe fruit, the shell is hard and brown. 807 represents ripe colouring on the whole surface of the fruit, and the bunch is ready for harvesting. 809 represents the over-ripening of the fruit and the bunch.

Fig. 4. Dynamique des changements de stade phénologique des inflorescences femelles et du développement des fruits chez les palmiers de 6 ans (A) et 11 ans (B) avec et sans irrigation.

Les lignes pleines indiquent les palmiers à huile témoins et les lignes pointillées indiquent les palmiers à huile avec irrigation. Les photos montrent l'évolution de l'inflorescence femelle de la pré-anthèse jusqu'à la fructification. Le code BBCH était le suivant (Forero et al., 2012) : 601 représente le stade pré-anthèse de l'inflorescence femelle. 607 représente l'anthèse de l'inflorescence femelle. 609 représente la fin de la floraison. 700 représente le stade de la fleur femelle fécondée. 703 représente le stade où le fruit atteint $30 \%$ de sa taille finale. 708 représente $80 \%$ de la taille finale du fruit. 709 représente des fruits de taille normale. 800 indique le stade auquel le fruit atteint sa taille finale et change de couleur de bas en haut à sa couleur mûre caractéristique. 805 représente un fruit presque mûr, la coque est dure et brune. 807 représente une coloration mûre sur toute la surface du fruit et le régime est prêt pour la récolte. 809 représente la surmaturation du fruit et du régime.

in the absence of water reservoirs (e.g., when epiphytic plants attached to palm trunks and the holes of cut leaves), low OP microenvironmental moisture has been observed, while the evaporative demand has been observed increasing (Röll et al., 2015).

Supplementary irrigation practices could positively influence the female inflorescence development and fruit ripening stages of OP trees. At 6 and 11yOP, irrigation was likely to foster an early development from the emergence of female inflorescences to the observation of fruit formation (code 700), shortening the time period to 80 days. However, the number of days required to pass from full fruit size (code 709) to bunches that were ready for harvesting (code 807) took longer, approximately 79 days versus the 61-65 days required without irrigation. Forero et al. (2012) in OP trees without irrigation, observed durations of the stages of emergence of inflorescences to anthesis (code 607) of 41.7 to 50.9 days, depending on the cultivar, but they did not show data on the number of days at the end of flowering or fruit maturation for comparison with what was observed in our study. The palms under study took an average of 48.7 days to go from code 601 to 607. No references were found related to the effects of supplementary irrigation or water deficit on the fruit ripening development stages in OP.

At physiological level, the precocity to anthesis showed by palms in the irrigation treatments could be related to sourcedemand relationships due to a higher photosynthetic activity and translocation into phloem; and the delay in fruit maturation with competition among demands during bunches production. Studies on the effects of water deficit on the inflorescence period, during the sex determination phase ( 29 months before harvesting) and the floral abortion (10 months before harvesting) showed the importance of carbohydrates supply (Combres et al., 2013; Suharyanti et al., 2020).

\section{Conclusion}

OP crops are relatively new in Tabasco, and irrigation practices are not applied by producers. The results of this study are the first attempt to test the effects of supplementary irrigation on the water flow and morphological changes from the emergence of female inflorescences to fruit ripening stages in OP trees. Complementary irrigation did not influence the sap flow quantity, but affected the duration of the phenological stages from the emergence of female inflorescences to anthesis, and from the full fruit size stage to bunches that were ready for harvesting. If the observed morphological changes based on $\mathrm{BBCH}$ codes are confirmed in other dry seasons, then these changes could be a rapid indicator used to evaluate supplemental irrigation practice effects in OP. To confirm the results obtained, the application of supplementary irrigation must be evaluated during at least three dry periods (i.e., 3 years), together with the study of dynamics of leaves production, the development rate of emergence of inflorescences to the fruit ripening and reproductive characteristics such as the numbers and weights of produced bunches.

Acknowledgements. We thanks the Partnership for International Research and Education (PIRE) project for financial support and the owner of the OP plantation in Tacotalpa for providing the facilities to carry out this study.

\section{References}

Allen R, Smith M, Perrier A, Pereira LS. 1994. An update for the definition of reference evapotranspiration. ICID Bulletin 43: 1-34. Bleiholder H, Van Den Boom T, Langelüddecke P, Stauss R. 1991. Codificación uniforme para los estadios fenológicos de las plantas cultivadas y de las malas hierbas. Phytoma 28: 54-56.

Breure CJ. 2010. Rate of leaf expansion: A criterion for identifying oil palm (Elaeis guineensis Jacq.) types suitable for planting at high densities. NJAS - Wageningen Journal of Life Sciences 57: 141-147. https://doi.org/10.1016/j.njas.2010.03.001.

Carr MKV. 2011. The water relations and irrigation requirements of oil palm (Elaeis guineensis): A review. Experimental Agriculture 47(4): 629-652. https://doi.org/10.1017/S0014479711000494.

Combres JC, Pallas B, Rouan L, Mialet-Serra I, Caliman JP, Braconnier S, et al. 2013. Simulation of inflorescence dynamics in oil palm and estimation of environment-sensitive phenological 
phases: a model based analysis. Functional Plant Biology 40: 263-279. https://doi.org/10.1071/FP12133.

Corley RHV, Tinker PBH. 2015. The oil palm. 5th ed. World Agriculture Series. Oxford (UK): Wiley Blackwell, 639p. https:// doi.org/10.1002/9781118953297.

Cornaire B, Daniel C, Lamade E, Fodil Z. 1994. Comportamiento de la palma de aceite bajo estrés hidrico. Palmas 15: 61-70.

Dufrene E, Saugier B. 1993. Gas exchange of oil palm in relation to light, vapor pressure deficit, temperature and leaf age. Functional Ecology 7(1): 97-104. https://doi.org/10.2307/2389872.

Dufrene E, Dubos B, Rey H, Quencez P, Saugier B. 1992. Changes in evapotranspiration from an oil palm stand (Elaeis guineensis Jacq.) exposed to seasonal soil water deficits. Acta Oecologica 13:299-314.

Fan Y, Roupsard O, Bernoux M, Le Maire G, Panferov O, Kotowska MM, et al. 2015. A sub-canopy structure for simulating oil palm in the Community Land Model (CLM-Palm): phenology, allocation and yield. Geoscientific Model Development 8: 3785-3800. https:// doi.org/10.5194/gmd-8-3785-2015.

FAOSTAT. 2020. Datos sobre alimentación y agricutura. http://www. fao.org/faostat/es/\#data/QC/visualize (Consultado el 13 de marzo de 2020).

Forero DC, Hormaza P, Romero HM. 2012. Phenological growth stages of African oil palm (Elaeis guineensis). Annals of Applied Biology 160: 56-65. https://doi.org/10.1111/j.1744-7348.2011.00520.x.

Granier A. 1985. Une nouvelle méthode pour la mesure du flux de sève brute dans le tronc des arbres. Annals of Forest Science 42: 193-200. https://doi.org/10.1051/forest:19850204.

Hardanto A, Röll A, Niu F, Meijide A, Hendrayanto, Hölscher D. 2017. Oil palm and rubber tree water use patterns: Effects of topography and flooding. Frontiers in Plant Science 8: 452. https:// doi.org/10.3389/fpls.2017.00452.

Henson IE, Mohd RMDN, Mohd HH, Zuraidah Y, Siti NAM. 2005. Stress development and its detection in young oil palms in North Kedah, Malaysia. Journal of Oil Palm Research 17: 11-26.

Hernández-Rojas DA, López-Barrera F, Bonilla-Moheno M. 2018. Preliminary analysis of the land use dynamic with oil palm (Elaeis guineensis) plantations in Mexico. Agrociencia 52: 875-893.

Hoffman MP, Castaneda VA, van Wijk MT, Giller KE, Oberthür T, Donough C, et al. 2014. Simulating potential growth and yield of oil palm (Elaeis guineensis) with PALMSIM: Model description, evaluation and application. Agricultural Systems 131: 1-10. https:// doi.org/10.1016/j.agsy.2014.07.006.

INIFAP. 2011. Paquete Tecnológico Palma de Aceite (Elaeis guineensis Jack.). Establecimiento y mantenimiento. In: Programa Estratégico para el Desarrollo Rural Sustentable de la Región Sur-Sureste de México: Trópico Húmedo 2011, Instituto Nacional de Investigaciones Forestales, Agrícolas y Pecuarias. Campo Experimental Rosario Izapa, Tuxtla Chico, Chiapas, $23 \mathrm{p}$.
Kallarackal J, Jeyakumar P, George SJ. 2004. Water use of irrigated oil palm at three different arid locations in peninsular India. Journal of Oil Palm Research 16(1): 45-53.

Legros S, Mialet-Serra I, Caliman JP, Siregar FA, Clement-Vidal A, Fabre D, et al. 2009. Phenology, growth and physiological adjustments of oil palm (Elaeis guineensis) to sink limitation induced by fruit pruning. Annals of Botany 104: 1183-1194. https:// doi.org/10.1093/aob/mcp216.

Meier U. 1997. Growth stages of mono-and dicotyledonous plants. Berlin (Allemagne): Blackwell Wissenschafts-Verlag. https://doi. org/10.5073/20180906-074619.

Niu F, Röll A, Hardanto A, Meijide A, Kohler M, Hendrayanto, et al. 2015. Oil palm water use: calibration of a sap flux method and a field measurement scheme. Technical Note. Tree Physiology 35(5): 563-573. https://doi.org/10.1093/treephys/tpv013.

Ochs R, Daniel C. 1976. Research on techniques adapted to dry regions. In: Corley RHV, Hardon JJ, Wood BJ, eds. Oil palm research. Amsterdam (The Netherlands): Elsevier, pp. 315-330.

Palma-López DJ, Triano A. 2002. Plan de uso sustentable de los suelos de Tabasco, Vol. II. Colegio de Postgraduados-ISPROTAB, ISBN: 9688393622.

Palma-López DJ, Palma-Cancino DJ, Jiménez-Jiménez R, Obrador-Olán J. 2017. Quality of the irrigation water in two zones of Tabasco, Mexico, with potential to cultivate oil palm (Elaeis guineensis Jacq). Agroproductividad 10(12): 64-70.

Rivera Méndez YD, Moreno Chacón L, Bayona JC, Romero MH. 2012. Physiological response of oil palm interspecific hybrids (Elaeis oleifera H.B.K. Cortes versus Elaeis guineensis Jacq.) to water deficit. Brazililian Society of Plant Physiology 24(4): 273-280. https://doi.org/10.5194/bg-12-5619-2015.

Röll A, Niu F, Meijide A, Hardanto A, Hendrayanto, Knohl A, et al. 2015. Transpiration in an oil palm landscape: Effects of palm age. Biogeosciences 12: 5619-5633. https://doi.org/10.5194/bg12-5619-2015.

Salgado-García S, Palma-López DJ, Zavala-Cruz J, Lagunes-Espinoza LC, Córdova-Sánchez S, Castelán-Estrada M, et al. 2017. Recomendaciones de fertilizantes en palma de aceite en la Región de los Ríos de Tabasco. H. Cárdenas, Tabasco, México: Grupo SIRDF-PA, Colegio de Postgraduados, Campus Tabasco, $69 \mathrm{p}$. ISBN: 9786077153436.

SAS University. 2018. Statistical software for academic, non commercial use. Cary NC, USA.

SIAP. 2017. Servicio de Información Agrialimentaria y Pesquera. Estadísticas de producción agrícola 2017. infosiap.siap.gob.mx/ gobmx/datosAbiertos_a.php (Consultado el 25 septiembre de 2017).

Suharyanti NA, Mizuno K, Sodr A. 2020. The effect of water deficit on inflorescence period at palm oil productivity on peatland. In: E3S Web of Conferences 211, 05005. The 1st JESSD Symposium 2020. https://doi.org/10.1051/e3sconf/202021105005.

Cite this article as: Mendoza-Hernández JHR, Vázquez-Navarrete CJ, Lagunes-Espinoza LdC, Rincón-Ramírez JA, del Rivero-Bautista N, Pérez-Bonilla MdC, Gutiérrez-López J, Asbjornsen H. 2021. Effect of supplementary irrigation on the transpiration and reproductive development of oil palm trees during the dry season in Tabasco, Mexico. Cah. Agric. 30: 41. 